\title{
Differences in gene activity in a Drosophila species cluster belonging to the Obscura group
}

\author{
M. D. MOLTÓ, M. J. MARTÍNEZ-SEBASTIÁN \& R. DE FRUTOS \\ Department of Genetics, University of València, Dr. Moliner 50, 46100 Burjassot, València, Spain
}

\begin{abstract}
The polytene chromosome puffing pattern of Drosophila madeirensis was established and compared with those of the related species D. subobscura and D. guanche. A total of 145 loci, active in some of the 12 developmental stages analysed, were described, 38 of which were found to form the puffing pattern characteristic to this species. Taking into account the number of puffs as well as the mean puff expression, $D$. madeirensis shows a similar activity level to $D$. guanche, both species being less active than $D$. subobscura. The low gene activity of $D$. madeirensis and $D$. guanche was explained as a consequence of their ecological characteristics.
\end{abstract}

Keywords: developmental puff, Drosophila, gene activity, inbreeding, obscura group, polytene chromosome.

\section{Introduction}

Drosophila subobscura, D. guanche and D. madeirensis are closely related species that form a cluster which differs from the other Drosophila species of the obscura group (Cabrera et al., 1983; Krimbas \& Loukas, 1984; Cariou et al., 1988; Brehm \& Krimbas, 1990; González et al., 1990). In a previous work (Moltó et al., 1988) we compared the gene activity of $D$. subobscura and D. guanche throughout pre-pupal development, establishing that the latter species is less active. The low activity of $D$. guanche can be explained as a result of its special characteristics. While $D$. subobscura is distributed world wide, $D$. guanche is endemic to the Laurel forest of the Canary Archipelago. The natural populations of this species are small in size and inbreeding is probably high.

The present paper describes the puffing pattern found in D. madeirensis, as an approach to the study of the gene expression in this species. Because $D$. madeirensis shows identical geographical isolation (endemic to Madeira island), ecological conditions (resides in the Laurel forest) and natural populations which are small in size as occurs for $D$. guanche, we have also compared its puffing pattern with those of $D$. subobscura and D. guanche in order to check whether gene activity is also depressed in $D$. madeirensis.

\section{Materials and methods}

\section{Strain}

The $D$. madeirensis strain used in this analysis was the isoline Md1, coming from individuals captured on Madeira island. The autosomes of $D$. madeirensis are homosequential with the corresponding chromosomes of D. subobscura, $\mathrm{J}_{\mathrm{st}}, \mathrm{U}_{1+2}, \mathrm{E}_{\mathrm{st}}$ and $\mathrm{O}_{3}$ (Krimbas \& Loukas, 1984), while the $\mathrm{X}$ chromosome shows a different gene arrangement from any known arrangement of D. subobscura (Papaceit \& Prevosti, 1989).

\section{Stages analysed}

The puffing pattern of the salivary gland chromosomes of $D$. madeirensis was established at 12 stages during development: late third larval instar, and $0, \frac{1}{2} \mathrm{~h}, 1 \mathrm{~h}, 2 \mathrm{~h}$, $4 \mathrm{~h}, 10 \mathrm{~h}, 14 \mathrm{~h}, 16 \mathrm{~h}, 18 \mathrm{~h}, 22 \mathrm{~h}$ and $24 \mathrm{~h}$ after eversion of anterior spiracles. The stages were synchronized following the method described in Pascual et al. (1985).

\section{Experimental design}

A total of 20 individuals per stage and five nuclei per individual were analysed for each four autosomes. The sex chromosome (A) was analysed only in females (approximately half of the total). All experiments, 
cultures and cytological preparations were carried out at a controlled temperature of $19^{\circ} \mathrm{C}\left( \pm 1^{\circ} \mathrm{C}\right)$. The cultures were reared without overcrowding as described in Pascual et al. (1985).

Because of strong homologies between the polytene chromosome banding patterns of $D$. madeirensis and $D$. subobscura, the location of the $D$. madeirensis puffs was determined by reference to the standard salivary gland chromosome map of D. subobscura (KunzeMühl \& Müller, 1958). To characterize a puff, three levels of development have been considered: (i) level (0) - no puffing, normal band morphology; (ii) level (1) - low degree of development; (iii) level (2) -medium or maximum level of development.

In order to quantify a puff frequency, the two designations $(+)$ or $(+/-)$ are used. A puff may be noted as $(+)$ when all five chromosomes analysed within a gland show a (2) level of puffing or $(+/-)$ when the puffing level varies between $(2)$ and $(0)$ in the same gland. The results are given in percentages.

\section{Coefficient of biological distance}

The distance coefficient $D_{\mathrm{K}}{ }^{2}$ (Kurczinsky, 1970) was calculated in order to quantify the degree of similarity between each pair of species belonging to the triad $D$. madeirensis-D. subobscura-D. guanche. It was cal- culated as described in Latorre et al. (1988), and was applied for each chromosome separately and for each species considering, in this case, all chromosomes. This coefficient was used because it can be statistically tested by the multivariant $T^{2}$ of Hotelling. For large samples, as in our case, $T^{2}$ is distributed approximately as $x^{2}$ with $r$ (= total puffs studied) degrees of freedom. Dendrograms were constructed following the UPGMA method (Sneath \& Sokal, 1973).

\section{Results}

\section{Pattern of puffing activity in $\mathrm{D}$. madeirensis}

A total of 145 loci active in some of the 12 developmental stages studied is described in this species. The distribution of these puffs on the chromosome is as follows: 18 on chromosome A, 29 on chromosome J, 29 on chromosome U, 32 on chromosome E and 37 on chromosome O. D. madeirensis also shows one Balbiani ring on chromosome $\mathrm{J}$ (section 24), that is active throughout all developmental stages studied. The puffs described in this species show variable levels of activity. We considered three classes of puffs according to their $(+)$ and $(+/-)$ percentages of appearance (Table 1). The group of puffs showing percentages equal or superior to 75 per cent, in at least one of the

Table 1 Classification of the D. madeirensis puffs according to their $(+/-)$ and $(+)$ percentages of appearance. Characteristic pattern puffs ( $\geq 75 \%$ ); puffs showing medium frequency $(25-75 \%)$ and occasional puffs $(\leq 25 \%)$. The order of the puffs is given according to their position in the chromosome arrangements found in this species

\begin{tabular}{|c|c|c|c|}
\hline Chromosome & $\geq 75 \%$ & $25-75 \%$ & $\leq 25 \%$ \\
\hline A & $4 \mathrm{~A}, 10 \mathrm{AB}, 12 \mathrm{AC}, 16 \mathrm{~B}$ & $\begin{array}{l}6 \mathrm{CD}, 11 \mathrm{D}, 13 \mathrm{~A}, 13 \mathrm{BC} \\
13 \mathrm{E}, 15 \mathrm{DE}\end{array}$ & $\begin{array}{l}1 \mathrm{C}, 6 \mathrm{E}-7 \mathrm{~A}, 2 \mathrm{C}, 8 \mathrm{D} / \mathrm{E} \\
8 \mathrm{E} / 9 \mathrm{~A}, 9 \mathrm{~B}, 12 \mathrm{D}, 14 \mathrm{C} / \mathrm{D}\end{array}$ \\
\hline $\mathbf{J}$ & $\begin{array}{l}18 \mathrm{C}, 25 \mathrm{AC}, 33 \mathrm{~B}-34 \mathrm{~A} \\
35 \mathrm{AB}\end{array}$ & $\begin{array}{l}17 \mathrm{AB}, 17 \mathrm{C} / \mathrm{D}, 19 \mathrm{AB}, \\
20 \mathrm{BC}, 21 \mathrm{D}-22 \mathrm{~A}, 22 \mathrm{~B}, \\
22 \mathrm{CD}, 22 \mathrm{E}-23 \mathrm{~A}, 26, \\
28 \mathrm{BC}, 30 \mathrm{~A}, 30 \mathrm{BC}, 31 \mathrm{~A}, \\
33 \mathrm{~A}, 34 \mathrm{~B}, 35 \mathrm{E}\end{array}$ & $\begin{array}{l}17 \mathrm{~B} / \mathrm{C}, 27 \mathrm{~A}, 28 \mathrm{~A} \\
28 \mathrm{D}, 29 \mathrm{~A}, 29 \mathrm{~B}, 31 \mathrm{BC} \\
32 \mathrm{~A}, 35 \mathrm{D}\end{array}$ \\
\hline $\mathrm{U}$ & $\begin{array}{l}37 \mathrm{AC}, 38 \mathrm{BC}, 39 \mathrm{~A}, 41 \mathrm{BD} \\
40 \mathrm{D}-41 \mathrm{~A}, 49 \mathrm{~B}, 48 \mathrm{D}, 48 \mathrm{~B} \\
47 \mathrm{BD}, 46 \mathrm{~B}, 52 \mathrm{AC}, 53 \mathrm{~B}\end{array}$ & $\begin{array}{l}37 \mathrm{D}-38 \mathrm{~A}, 43 \mathrm{CD}, 50 \mathrm{D}, \\
50 \mathrm{~B}, 48 \mathrm{~A}, 51 \mathrm{D}\end{array}$ & $\begin{array}{l}36 \mathrm{AB}, 36 \mathrm{C}, 39 \mathrm{D} \\
44 \mathrm{C}-45 \mathrm{~A}, 42 \mathrm{C} / 43 \mathrm{~A} \\
42 \mathrm{~B} / \mathrm{C}, 42 \mathrm{~A} / \mathrm{B}, 40 \mathrm{~A} / \mathrm{B} \\
49 \mathrm{~A}, 46 \mathrm{D}, 53 \mathrm{D}\end{array}$ \\
\hline $\mathrm{O}$ & $\begin{array}{l}75 \mathrm{C}-76 \mathrm{~A}, 78 \mathrm{BC} \\
82 \mathrm{~B}-83 \mathrm{C}, 85 \mathrm{AB} \\
86 \mathrm{~A}, 97 \mathrm{DE}\end{array}$ & $\begin{array}{l}76 \mathrm{~B}, 79 \mathrm{~B}, 82 \mathrm{~A} / \mathrm{B} \\
87 \mathrm{C}, 88 \mathrm{D}-89 \mathrm{~A}, 90 \mathrm{D} \\
91 \mathrm{C}-92 \mathrm{~A}, 95 \mathrm{~A}, 95 \mathrm{C}, 95 \mathrm{D}, \\
96 \mathrm{AC}, 98 \mathrm{C}, 99 \mathrm{BC}\end{array}$ & $\begin{array}{l}76 \mathrm{D}, 78 \mathrm{D}, 79 \mathrm{D}-80 \mathrm{~A}, \\
80 \mathrm{D} / 81 \mathrm{~A}, 81 \mathrm{BC}, 84 \mathrm{C} / \mathrm{D}, \\
85 \mathrm{CD}, 87 \mathrm{AB}, 88 \mathrm{~A}, 90 \mathrm{~A}, \\
90 \mathrm{~B}, 91 \mathrm{~B}, 94 \mathrm{C}, 94 \mathrm{~A}, \\
92 \mathrm{D}-93 \mathrm{~A}, 92 \mathrm{C}, 92 \mathrm{AB}, \\
97 \mathrm{AB}\end{array}$ \\
\hline
\end{tabular}




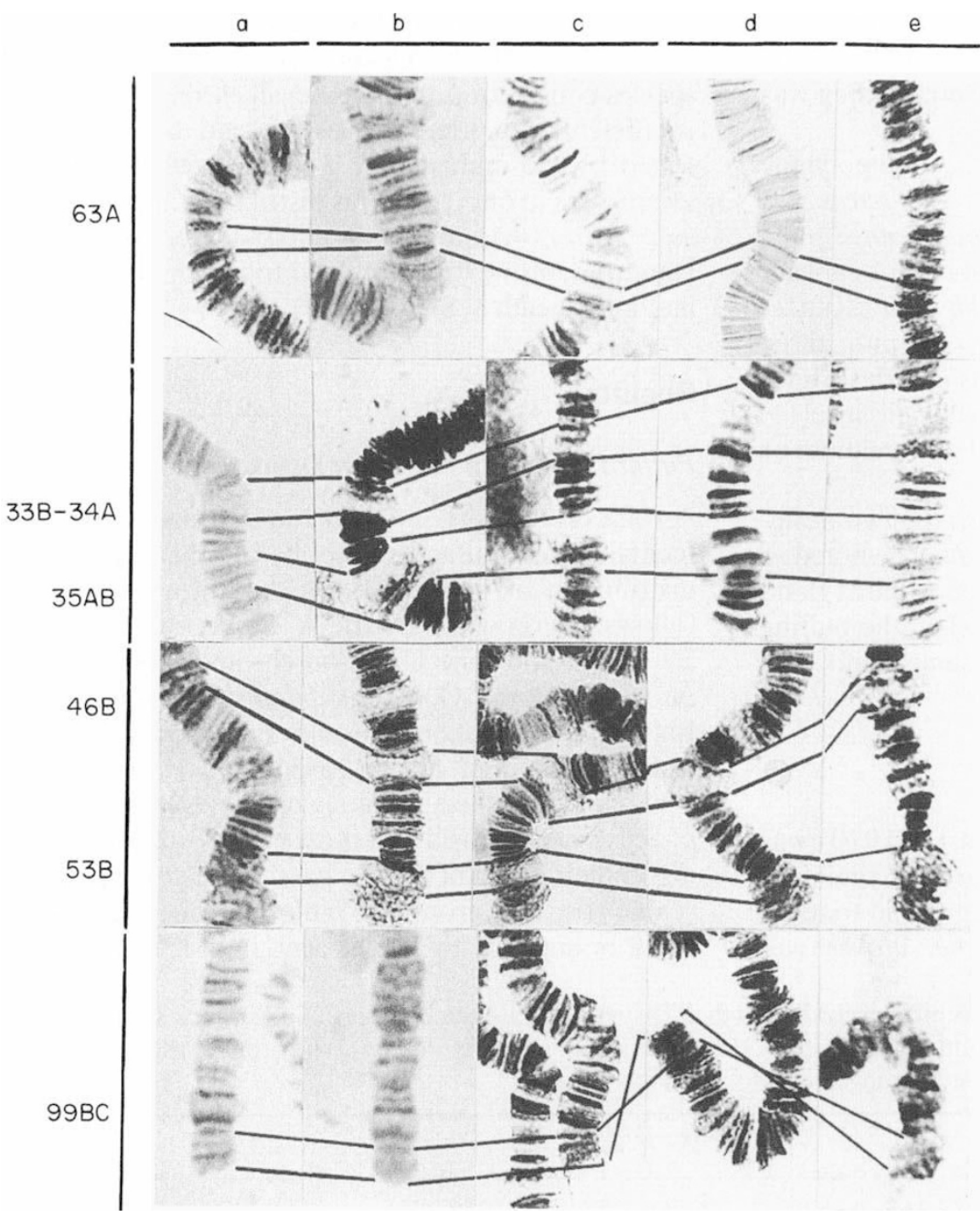

Fig. 1 Temporal puffing sequences of some D. madeirensis puffs which show high or medium frequency. Third instar larvae (a), beginning of prepupation (b), prepupation $(\mathrm{c}-\mathrm{d})$, end of prepupation (e). stages studied, has been taken as the characteristic puffing pattern of this species. A total of 38 loci (26 per cent of the puffs described in $D$. madeirensis) forms the characteristic puffing pattern of this species. A second class of puffs is formed by 49 loci ( 34 per cent of the total) which reach a medium frequency (between 25 per cent and 75 per cent). Figure 1 gives puffing sequences found in some of these loci belonging to both classes of puffs. Some of them show higher activity at specific times during development, either in the third larval instar (63A puff), at the beginning of pre-pupation (35AB puff), or at the end of pre-pupation (99BC puff). Other loci are active at different developmental stages (33B-34A puff) or throughout all pre-pupal period (46B and 53B puffs). The rest of the $D$. madeirensis puffs (40 per cent) shows a frequency equal to or lower than 25 per cent in all stages analysed, being considered as occasional puffs. (The data for the frequency of each puff at each developmental stage fill 5 tables that are available on written request from the first author.)

\section{Comparison between the puffing pattern of $\mathrm{D}$.} madeirensis and those of $\mathrm{D}$. subobscura and $\mathrm{D}$. guanche

Due to the high degree of homology between the polytene chromosome banding patterns of $D$. madeirensis, $D$. subobscura and $D$. guanche, it is possible to establish a comparative analysis of the developmental puffing patterns of the three species. A total of 186 puffs are described among the three species, of which 166 are active in D. subobscura (Pascual et al., 1985), 150 in D. guanche (Moltó et al., 1988) and 145 in D. madeirensis. The characteristic puffing patterns of $D$. subobscura and $D$. guanche were established as was 
Fig. 2 Characteristic developmental puffing pattern of $D$. madeirensis (triangle), D. guanche (bar) and $D$. subobscura (circle). MGS, characteristic puffs common to the three species, D. madeirensis (M), D. guanche (G) and D. subobscura (S); MG, MS and GS, characteristic puffs of two species, respectively.
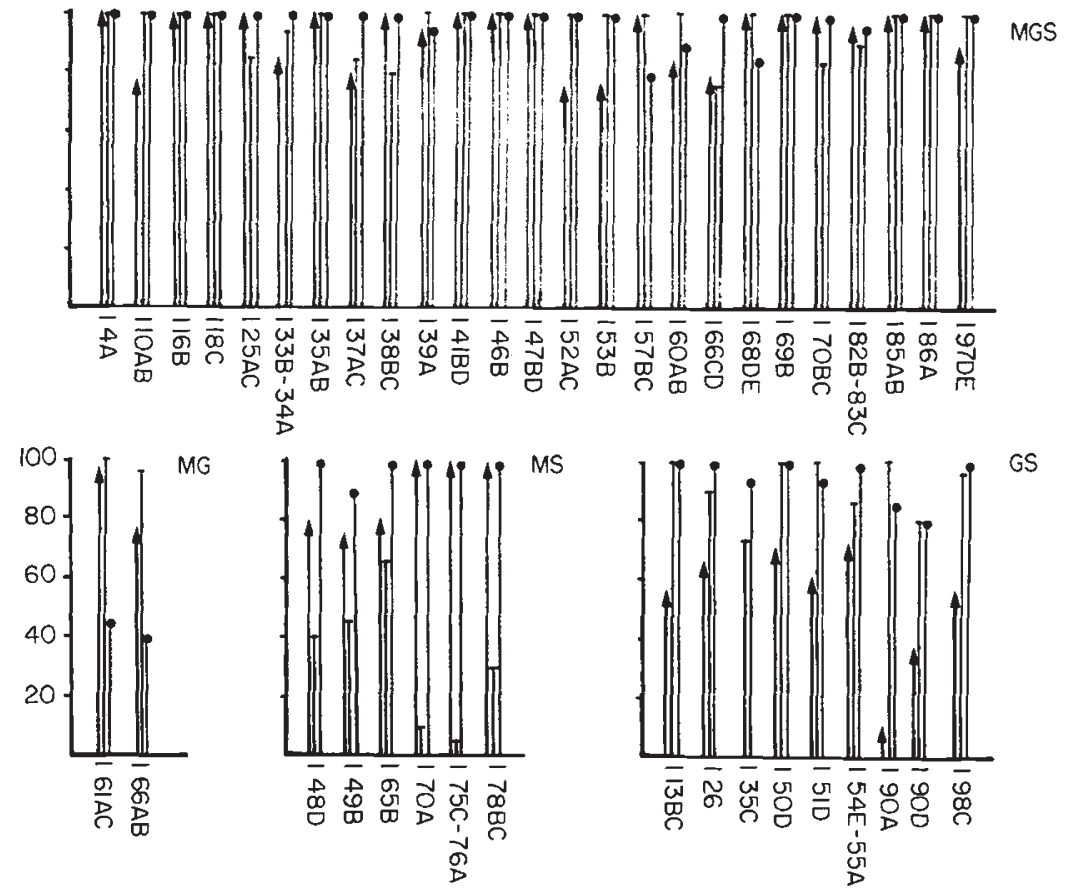

G

which are characteristic of one, two or the three species analysed. Twenty-five puffs are characteristic of $D$. madeirensis, D. guanche and D. subobscura (MGS), and also show, in all three species, the same temporal expression during development. They are the biggest puffs in all three species. In general, the puffs that are characteristic of only two species (MG, MS, GS) have a medium frequency in the third species. But for the puffs that are characteristic of only one species $\langle M, G$, S) higher heterogeneity in their activities has been observed in the other two species. For example $17 \mathrm{AB}$ puff is characteristic of $D$. subobscura, and reaches a medium frequency in $D$. madeirensis but is not active in D. guanche.

\section{Gene activity}

The puffing patterns of $D$. madeirensis, $D$. subobscura and $D$. guanche can also be compared by studying the mean gene activity of each species and also of each chromosome separately. For this reason, the A index described by Pascual et al. (1985) was used with some modifications. The mean gene activity of a species $\left(A_{\mathrm{s}}\right)$ may be estimated by counting the frequency of appearance of the total puffs in all developmental stages studied:

$A_{\mathrm{S}}=1 / k R \sum_{j=1}^{j=N} P_{\mathrm{j}}$,

where $R$ is the number of chromosomal regions analysed (99 in this case: 25 sections on the O chromo- 
some +21 on the $\mathrm{E}$ chromosome +19 on the $\mathrm{J}$ chromosome +18 on the $\mathrm{U}$ chromosome +16 on the $\mathrm{A}$ chromosome), $k$ is the number of developmental stages studied in each species, $N$ is the number of the total active loci observed in a species and $P$ is the frequency of finding a locus with level (2) of development. As can be seen in Table 2,D. subobscura shows more than double the activity found in $D$. madeirensis or $D$. guanche, while these two species have a similar level of activity.

Table 2 Values of the $A_{\mathrm{S}}$ index in the three species

\begin{tabular}{llll}
\hline & D. madeirensis & D. guanche & D. subobscura \\
\cline { 2 - 4 }$A_{\mathrm{S}}$ & 0.108 & 0.109 & 0.236 \\
\hline
\end{tabular}

The $\mathrm{A}$ index used to calculate the mean gene activity in a given stage of a species $\left(A_{\mathrm{T}}\right)$, is as follows:

$$
A_{\mathrm{T}}=1 / R \sum_{j=1}^{j=N} P_{\mathrm{j}} .
$$

For this index, $R$ is also 99. Figure 4(a) summarizes the results obtained. In all developmental stages analysed, $D$. madeirensis as well as $D$. guanche show lower levels of puffing than D. subobscura. While D. subobscura and $D$. guanche have a clear maximum at the beginning of prepupation, in $D$. madeirensis the levels of gene activity remain low throughout development.

The $\mathrm{A}$ index which gives the mean gene activity of a chromosome at a given stage in a species $\left(A_{\mathrm{C}}\right)$, was used in order to compare the three species at chromo-
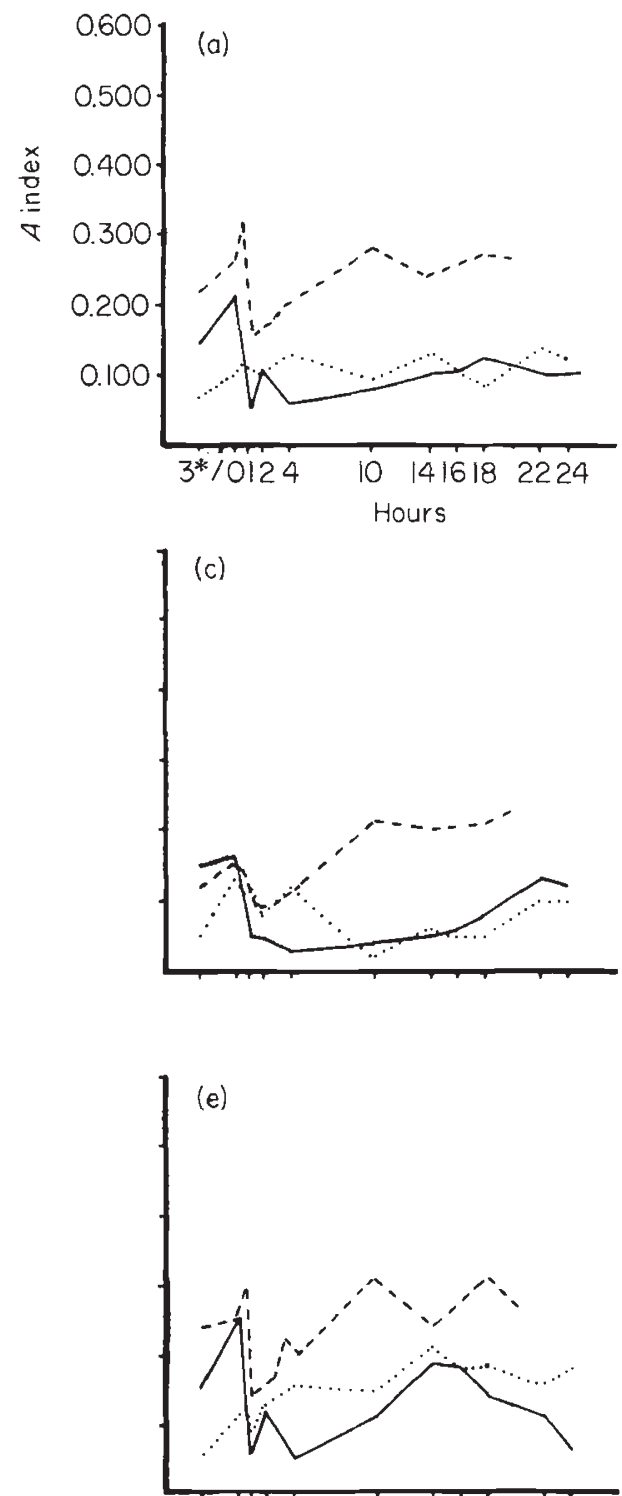
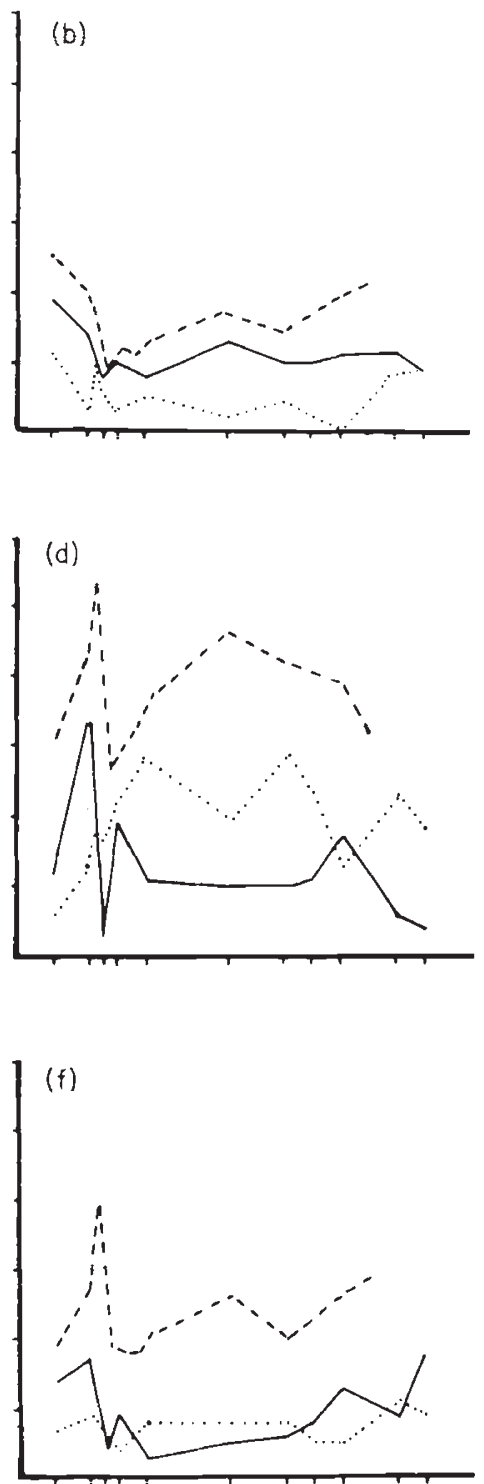

Fig. 4 Comparison of the $A_{\mathrm{T}}$ index (a) and $A_{C}$ index for: A chromosome (b), $\mathrm{J}$ chromosome (c), U chromosome (d), E chromosome (e), and $\mathrm{O}$ chromosome (f), between D. madeirensis (dotted line), D. guanche (continuous line) and D. subobscura (discontinuous line). The stages analysed are indicated on the $\mathrm{X}$ axis: late third larval instar $\left(3^{*}\right)$, and 0 to $24 \mathrm{~h}$ after eversion of anterior spiracles. 
some level:

$$
A_{\mathrm{C}}=1 / r \sum_{j=1}^{j=N} P_{\mathrm{j}}
$$

In this case, $r$ indicates the sections in which each chromosome is organized and $n$ is the number of active loci observed in this chromosome in a species. As shown in Fig. 4(b)-(f), for all chromosomes the gene activity in $D$. madeirensis and $D$. guanche is also lower than in D. subobscura. This difference is most marked in the $\mathrm{O}$ chromosome (Fig. 4f).

\section{Biological distance}

Because of a high number of occasional puffs described in each of the three species studied, the distance coefficient $D^{2}{ }_{\mathrm{K}}$ was calculated from those puffs showing development level (2) with a mean frequency equal or superior to 5 per cent, in at least one species. Table 3 gives the chromosomal location of the 89 puffs chosen following this criteria. These represent 48 per cent of the 186 puffs observed in the three species. Table 4 and Fig. 5 summarize the results obtained with $D_{\mathrm{K}}^{2}$ coefficient. Considering the data for all chromosomes (Fig. 5a) as for the five chromosomes separately (Fig. 5c-f), except the sexual chromosome (Fig. 5b), the two endemic species D. madeirensis and $D$. guanche are clustered, while $D$. subobscura is the most distant species. The sexual chromosome shows a clustering of $D$. subobscura and $D$. guanche, that could be explained by the low activity of $D$. madeirensis chromosome A. The global distance obtained between D. subobscura and any endemic species is in the order of twice the distance found between the two endemic species, in accordance with the $A_{S}$ values. Chromosomes $\mathrm{U}, \mathrm{E}$ and $\mathrm{O}$ contribute more strongly to the differentiation between $D$. subobscura and the cluster of $D$. madeirensis and $D$. guanche, than chromosomes $\mathrm{A}$ and $\mathrm{J}$. The latter chromosome shows a lesser difference in gene activity in the three species.

\section{Discussion}

According to our results, the most striking difference in the gene activity patterns of $D$. madeirensis, $D$. guanche

Table $4 D_{\mathrm{k}}^{2}$ distance values between each pair of the three species, $D$. madeirensis $(\mathrm{M}), D$. guanche $(\mathrm{G})$ and $D$. subobscura $(\mathrm{S})$. Values in parentheses are the multivariant $T^{2}$ of Hotelling and degrees of freedom, respectively

\begin{tabular}{llcl}
\hline & M-G & M-S & G-S \\
\hline All chromosomes & $10.3^{* *}$ & $22.1^{* *}$ & $25.4^{* *}$ \\
& $(299.4,89)$ & $(947.6,89)$ & $(1017.7,89)$ \\
Chromosome A & $2.1^{* *}$ & $2.9^{* *}$ & $1.9^{* *}$ \\
& $(57.2,11)$ & $(126.7,11)$ & $(71.5,11)$ \\
Chromosome J & $0.7^{*}$ & $1.5^{* *}$ & $1.7^{* *}$ \\
& $(30.7,13)$ & $(102.1,13)$ & $(103.2,13)$ \\
Chromosome U & $2.2^{* *}$ & $5.6^{* *}$ & $8.4^{* *}$ \\
& $(65.5,20)$ & $(242.2,20)$ & $(331.0,20)$ \\
Chromosome E & $2.3^{* *}$ & $5.6^{* *}$ & $6.8^{* *}$ \\
& $(60.5,22)$ & $(218.7,32)$ & $(244.5,22)$ \\
Chromosome O & $2.8^{* *}$ & $6.4^{* *}$ & $6.5^{* *}$ \\
& $(70.9,23)$ & $(237.8,23)$ & $(223.9,23)$ \\
\hline
\end{tabular}

${ }^{* *} P<0.001$

${ }^{*} P<0.005$.

Table 3 Chromosomal locations of the 89 puffs used in the calculation of the biological distance

\section{Chromosomes}

\begin{tabular}{llllllll}
\hline $\mathrm{A}$ & $\mathrm{J}$ & $\mathrm{U}$ & & $\mathrm{E}$ & & $\mathrm{O}$ & \\
\hline $2 \mathrm{C}$ & $17 \mathrm{AB}$ & $37 \mathrm{AC}$ & $49 \mathrm{~A}$ & $54 \mathrm{E}-55 \mathrm{~A}$ & $67 \mathrm{AB}$ & $75 \mathrm{C}-76 \mathrm{~A}$ & $92 \mathrm{AB}$ \\
$4 \mathrm{~A}$ & $18 \mathrm{C}$ & $37 \mathrm{D}-38 \mathrm{~A}$ & $49 \mathrm{~B}$ & $57 \mathrm{BC}$ & $68 \mathrm{DE}$ & $78 \mathrm{BC}$ & $92 \mathrm{D}-93 \mathrm{~A}$ \\
$5 \mathrm{D}$ & $21 \mathrm{D}-22 \mathrm{~A}$ & $38 \mathrm{BC}$ & $50 \mathrm{~B}$ & $59 \mathrm{E}$ & $69 \mathrm{~B}$ & $79 \mathrm{~B}$ & $94 \mathrm{C}$ \\
$10 \mathrm{AB}$ & $22 \mathrm{E}-23 \mathrm{~A}$ & $39 \mathrm{~A}$ & $50 \mathrm{D}$ & $60 \mathrm{AB}$ & $70 \mathrm{~A}$ & $82 \mathrm{~A} / \mathrm{B}$ & $95 \mathrm{C}$ \\
$12 \mathrm{AC}$ & $25 \mathrm{AC}$ & $39 \mathrm{D}$ & $51 \mathrm{D}$ & $60 \mathrm{C} / \mathrm{D}$ & $70 \mathrm{BC}$ & $82 \mathrm{~B}-83 \mathrm{C}$ & $95 \mathrm{D}$ \\
$12 \mathrm{D}$ & 26 & $40 \mathrm{D}-41 \mathrm{~A}$ & $52 \mathrm{AC}$ & $61 \mathrm{AC}$ & $72 \mathrm{BC}$ & $85 \mathrm{AB}$ & $96 \mathrm{AC}$ \\
$13 \mathrm{~A}$ & $28 \mathrm{BC}$ & $41 \mathrm{BD}$ & $53 \mathrm{~B}$ & $61 \mathrm{D}-62 \mathrm{~A}$ & $72 \mathrm{D}-73 \mathrm{~A}$ & $86 \mathrm{~A}$ & $97 \mathrm{AB}$ \\
$13 \mathrm{BC}$ & $28 \mathrm{D}$ & $43 \mathrm{CD}$ & & $63 \mathrm{~A}$ & $74 \mathrm{~A}$ & $87 \mathrm{C}$ & $97 \mathrm{DE}$ \\
$13 \mathrm{E}$ & $31 \mathrm{BC}$ & $46 \mathrm{~B}$ & & $63 \mathrm{~A} / \mathrm{B}$ & $74 \mathrm{BC}$ & $88 \mathrm{~A}$ & $98 \mathrm{C}$ \\
$15 \mathrm{DE}$ & $33 \mathrm{~B}-34 \mathrm{~A}$ & $47 \mathrm{BD}$ & & $63 \mathrm{~B} / \mathrm{C}$ & & $88 \mathrm{D}-89 \mathrm{~A}$ & $99 \mathrm{BC}$ \\
$16 \mathrm{~B}$ & $35 \mathrm{AB}$ & $48 \mathrm{~A}$ & & $65 \mathrm{~B}$ & & $90 \mathrm{~A}$ & $90 \mathrm{D}$ \\
& $35 \mathrm{C}$ & $48 \mathrm{~B}$ & & $66 \mathrm{AB}$ & & $91 \mathrm{C}-92 \mathrm{~A}$ & \\
& $35 \mathrm{E}$ & $48 \mathrm{D}$ & & $66 \mathrm{CD}$ & & & \\
\hline
\end{tabular}



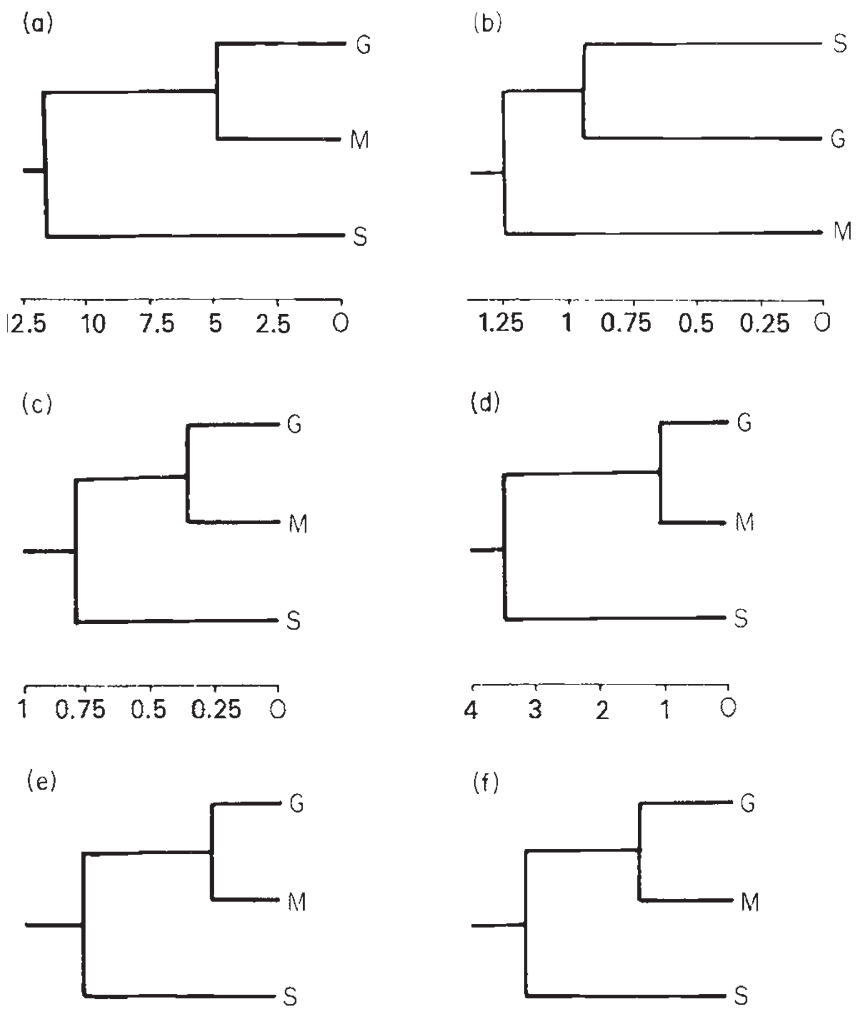

$\begin{array}{lllll}4 & 3 & 2 & 1 & 0\end{array}$
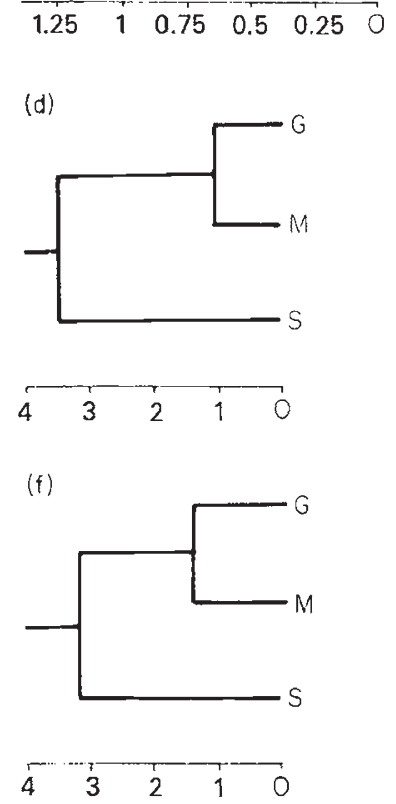

Fig. 5 Dendrograms of the three species studied, after combining the data for all chromosomes (a) and for each chromosome separately: A chromosome (b), J chromosome (c), U chromosome (d), E chromosome (e), O chromosome (f). The $D_{k}{ }^{2}$ distance values between each pair of the three species are indicated below the corresponding dendrogram.

and $D$. subobscura is the relatively low puff activity in first two species with respect to D. subobscura. This feature is observed on comparing the total number of active loci as well as the mean puff expression. $D$. subobscura's total activity is double that of $D$. madeirensis or D. guanche, these latter having similar puffing levels. Moreover, both species show relatively unchanged levels of gene activity during the pre-pupation period, in contrast to the typical Drosophila pattern shown by D. subobscura. The two major peaks in Drosophila gene activity pattern (at the beginning and the end of the pre-pupal stages) do not occur in D. madeirensis, while in $D$. guanche only the maximum appears at the beginning of pre-pupation.

When we compare the gene expression for the five chromosomes separately, a lower level of activity is observed in $D$. madeirensis and $D$. guanche than in $D$. subobscura. The biological distances calculated between the three species shows these findings. The two endemic species, D. madeirensis and D. guanche are clustered while $D$. subobscura is the most distant

species, in all cases with the exception of the A chromosome. Although D. subobscura and D. guanche show high structural differences in this chromosome (Moltó et al., 1987; Brehm \& Krimbas, 1990), both species are clustered for the A chromosome, while $D$. madeirensis is, in this case, the most different species. The low activity of $D$. madeirensis chromosome A, with respect to the other two species explains these data.

The relationships obtained in this work between $D$. madeirensis, D. subobscura and D. guanche from their puffing activity, are concordant with those inferred by Cabrera et al. (1983) based on electrophoretic comparisons. However in the latter work the distance between $D$. madeirensis and $D$. guanche is only slightly less than the distance of both species from $D$. subobscura. In the three depicted by Cariou et al. (1988), $D$. madeirensis-D. guanche was also the closest pair of the three species, but differed in the fact that the distance between $D$. subobscura-D. guanche was smaller than that of D. subobscura-D. madeirensis. In contrast, morphological characters, interspecific crosses and chromosomal homologies proved that $D$. subobscura is closer to D. madeirensis than to D. guanche, while this species is closer to D. madeirensis (Krimbas \& Loukas, 1984; Brehm \& Krimbas, 1990). Stronger differences were found between $D$. subobscura and $D$. guanche (Moltó et al., 1987) than between D. subobscura and D. madeirensis (Papaceit \& Prevosti, 1989). A first dichotomy giving $D$. guanche and a later one in which $D$. madeirensis and D. subobscura split off, was suggested by Krimbas \& Loukas (1984). The same conclusion was reached by Loukas et al. (1984) based on electrophoretic data and by Larruga \& Pinsker (1984) based on the genetic divergence of chromosome $\mathrm{O}$ in these species. Mitochondrial DNA analyses have also suggested the D. madeirensis $-D$. subobscura pair as the closest one (González et al., 1990). As can be seen, the phylogenetic relationships between the three species are still controversial: there is no consensus on the relative pairing of $D$. madeirensis, $D$. guanche and $D$. subobscura.

The weakening in puffing found in $D$. madeirensis and $D$. guanche with respect to $D$. subobscura, may be explained as a result of the special characteristics of these two species. Both species are insular endemic living in the last vestiges of laurisilva forests (Monclús, 1976, 1984). Their natural populations are geographically isolated and of small size, both characteristics favourable to inbreeding. In fact, an excess of homozygotes for allozyme variation was found in both species, and was attributed to their ecological conditions (González et al., 1983). According to Bachmann et al. (1989), a species-specific satellite DNA of $D$. guanche can be explained by the inbreeding and isola- 
tion of this species. Moreover, no polymorphism for mtDNA restriction sites was detected in $D$. guanche (González et al., 1990), establishing a bottle-neck effect in the populations of this species. For chromosomal gene arrangements, $D$. madeirensis as well as $D$. guanche also show high homogeneity. On the contrary, D. subobscura is a Palearctic species with wide geographical distribution, a rich chromosomal polymorphism and a higher mtDNA nucleomorph variation (Krimbas \& Loukas, 1980; Afonso et al., 1990).

A weakening in gene activity has already been described in the literature about an inbred line of $D$. melanogaster (Lychev, 1965). De Frutos et al. (1984) observed a general depression of the puffing activity in a $D$. subobscura laboratory strain $(\mathrm{K} 228)$ subjected to prolonged inbreeding, with respect to other $D$. $s u b$ obscura stocks. Differences in puffing are due to differences in the number of active loci as well as the mean gene activity. Only a certain number of puffs escape the inbreeding effect on gene activity. They are the characteristic pattern puffs common to all D. subobscura strains. Curiously, they are also present in the characteristic pattern of $D$. madeirensis and $D$. guanche (MGS puffs). These loci represent 14 per cent of the total puffs described among the three species and also have the same temporal expression during development in the three species. Thus, this little group of puffs constitutes the essential loci for the cellular life of these species at prepupal development, that is to say, they might represent the basic sequence for gene expression, as Ashburner et al. observed in related species (Ashburner \& Lemeunier, 1972; Ashburner \& Berendes, 1978).

Some of the remaining puffs could be related to fitness traits. It is well-known that inbreeding leads to a depression in the expression of traits pertaining to fitness. We have evidence that $D$. madeirensis shows a lower fertility and higher mortality than D. subobscura: inbreeding might provoke a negative control of gene expression, by lethal genes for example.

To conclude, the low puff activity in $D$. madeirensis as well as in $D$. guanche with respect to $D$. subobscura could be explained by the inbreeding effect, which leads to a general depression in gene expression (as occurs in an inbred line of D. subobscura). We think it is most likely that the clustering obtained for the three species could also be affected by inbreeding.

\section{Acknowledgements}

We would like to thank Dr Prevosti for providing the D. madeirensis stock. M. D. Moltó was supported by a grant from Conselleria de Cultura, Educaciò i Ciència of Generalitat Valenciana.

\section{References}

AFONSO, J. M., VOLZ, A., HERNANDEZ, M., RUTTKAY, H., GONZALEZ, M., LARRUGA, J. M., CABRERA, V. M. AND SPERLICH, D. 1990. Mitochondrial DNA variation and genetic structure in old world populations of Drosophila subobscura. Mol. Biol. Evol., 7, 123-142.

ASHBURNER, M. AND BERENDES, H. D. 1978. Puffing of polytene chromosomes. In: Ashburner, M. and Wright, T. R. F. (eds) The Genetics and Biology of Drosophila, Academic Press, New York, vol. 2b, pp. 315-395.

ASHBURNer, M. AND LEMEUNiER, F. 1972. Patterns of puffing activity in the salivary gland chromosomes of Drosophila. VII: Homology of puffing patterns on Drosophila yakuba, with notes on puffing in Drosophila teissieri. Chromosoma, 38, 283-295.

BACHMANN, L., RAAB, M. AND SPERLICH, D. 1989. Satellite DNA and speciation: a species specific satellite DNA of Drosophila guanche. Z. zool. Syst. Evolut.-forsch., 27, 84-93.

BELYAEVA, E. S. AND ZHIMULEV, P. F. 1974. Variation in the size of puffs in D. melanogaster. Genetika, 10, 74-80.

BREHM, A. AND KRIMBAS, C. B. 1990. Evolution of the obscura group Drosophila species. III. Phylogenetic relationships in the subobscura cluster based on homologies of chromosome A. Heredity, 65, 269-275.

CABRERA, v. M., GONZALEZ, A. M., LARRUGA, J. M. AND GULlon, A 1983. Genetic distance and evolutionary relationships in the Drosophila obscura group. Evolution, 37, 635-689.

CARIOU, M. L., LACHAISE, D., TSACAS, L., SOURDIS, J., KRIMBAS, C. B. AND ASHBURNER, M. 1988. New African species in the Drosophila obscura species group: genetic variation, differentiation and evolution. Heredity, 61, 73-84.

DE FRUTOS, R., LATORRE, A. AND PASCUAL, L. 1984. Patterns of puffing activity and chromosomal polymorphism in Drosophila subobscura. 3. Puffing activity depression by inbreeding. Theor. Appl. Genet., 69, 101-110.

GONZÁleZ, A. M., CABRERA, v. M., LARRUGA, J. M. AND GULlon, A. 1983. Molecular variation in insular endemic Drosophila species of the Macaronesian Archipelagos. Evolution, 37, 1128-1140.

GONZALEZ, A. M., HERNANDEZ, M., VOlZ, A., PESTANO, J., LARRUGA, J. M., SPERLICH, D. AND CABRERA, V. M. 1990. Mitochondrial DNA evolution in the obscura species subgroup of Drosophila. J. Mol. Evol., 31, 122-131.

KRIMBAS, C. B. AND LOUKAS, M. 1980. The inversion polymorphism of Drosophila subobscura. Evol. Biol., 12, 163-234.

KRIMBAS, C. B. AND LOUKAS, M. 1984. Evolution of the obscura group Drosophila species. I. Salivary chromosomes and quantitative characters in Drosophila subobscura and two closely related species. Heredity, 53, 469-482.

KUNZE-MÜHL, E. AND MÜLLER, E. 1958. Weitere Undersunchungen über die chromosomale Struktur und die natürslichen Strukturtypen von Drosophila subobscura Coll. Chromosoma, 9, 559-570.

KURCZYNSKY, T. w. 1970. Generalized distance and variables. Biometrics, 26, 525-534.

LARRUGA, J. M. AND PINSKER, w. 1984. The importance of geographic isolation, structural rearrangement and speciation for the genetic divergence of chromosome $\mathrm{O}$ in Droso- 
phila subobscura, Drosophila guanche and Drosophila madeirensis. Z. zool. Syst. Evolut.-forsch., 22, 103-113.

LATORRE, A., MOYA, A. AND DE FRUTOS, R. 1988. Patterns of puffing activity and chromosomal polymorphism in Drosophila subobscura. IV. Effect of inversions on gene expression. Evolution, 42, 1298-1308.

LOUKAS, M., KRIMBAS, C. B. AND VERGINI, Y. 1984. Evolution of the obscura group Drosophila species II. Phylogeny of ten species based on electrophoretic data. Heredity, 53, 483-493.

LYCHEv, v. A. 1965 . A study of chromosomal activity during continuous inbreeding in Drosophila. Tsitologiya, 7, 325-333.

MOLTO, M. D., DE FRUTOS, R. AND MARTINEZ-SEBASTIAN, M. J. 1987. The banding pattern of polytene chromosomes of Drosophila guanche compared with that of $D$. subobscura. Genetica, 75, 55-70.

MOLTO, M. D., DE FRUTOS, R. AND MARTINEZ-SEBASTIAN, M. J. 1988. Gene activity of polytene chromosomes in Drosophila species of the obscura group. Chromosoma, 96, 382-390.

MONCLÚs, M. 1976. Distribución y Ecología de Drosofilidos en España. II. Especies de Drosophila de las Islas Canarias con la descripción de una nueva especie. Bol. $R$. Soc. Española Hist. Nat. (Biol.), 74, 197-213.

MONCLÚs, M. 1984. Drosophilidae of Madeira, with the description of Drosophila madeirensis n.sp. Z. zool. Syst. Evolut.-forsch., 22, 94-103.

PAPACEIT, M. AND PREVOSTI, A. 1989. Differences in chromosome A arrangement between Drosophila madeirensis and Drosophila subobscura. Experientia, 45, 310-312.

PASCUAL, L., LATORRE, A. AND DE FRUTOS, R. 1985. Patterns of puffing activity and chromosomal polymorphism in Drosophila subobscura. II. Puffing patterns at the prepupa stage. Genetica, 66, 123-138.

SNEATH, P. H. A. AND SOKAL, R. R. 1973. Numerical Taxonomy. Freeman, San Francisco, CA. 